\title{
Incidence of Sucking Pests and Natural Enemies in Cotton under High Density Planting System (HDPS)
}

\author{
N. Rajasekhar $^{1 *}$ and N.V.V.S. Durga Prasad ${ }^{2}$ \\ ${ }^{1}$ Department of Entomology, Agricultural College, Bapatla, ANGRAU, India \\ ${ }^{2}$ Senior scientist (Entomology), RARS, Lam, Guntur, ANGRAU, India \\ *Corresponding author
}

\section{A B S T R A C T}

\section{Keywords \\ Leafhoppers, Aphids, Thrips, Whitefly, Spiders, \\ Coccinellids, Normal spacing and HDPS}

\section{Article Info}

Accepted: 20 April 2018 Available Online: 10 May 2018
The study on "Incidence of sucking pests and natural enemies in cotton under high density planting system (HDPS)" was conducted at RARS, Lam, Guntur during kharif, 2016-17 to observe the incidence of sucking pests such as leafhoppers, aphids, thrips and whitefly and also the incidence of natural enemies (Spiders and Coccinellids). Among the sucking pests thrips population was found dominating other sucking pests during initial days of crop growth period i.e., up to 90 DAS there after aphid population was dominated i.e., from 90135 DAS both in normal and HDPS. Leafhopper and whitefly population did not show any significant difference between both normal and HDPS. Leafhopper population crossed ETL only at 45 and 75 DAS but whitefly population did not cross the ETL throughout crop growth period. Spider population was coincided with the incidence of aphid population during 90-135 DAS.

\section{Introduction}

By 1996 the world realized the cultivation of transgenic Bt cottons expressing Cry 1 Ac delta endotoxin as an ultimate resort to mitigate bollworm menace. The transgenic cotton showed great resistance against Helicoverpa armigera (Hub.) Pectinophora gossypiella (Saund.), Earias vittella (Fab.) and E. insulana (Biosd.) both under field and laboratory conditions (Kranthi and Kranthi, 2004). Bt toxins can effectively control specific lepidopterous species, but lack resistance against sucking insect pests (Hofs $e t$ al., 2004; Sharma and Pampapthy, 2006). In the impact assessment of transgenic cottons a little attention has been given on the changing dynamics of sucking pests and other non target organisms. With Bt cottons it has been experienced that reduction in usage of insecticides lead to increased population of sucking insect pests (Men et al., 2005). Thus, in Bt cotton era sucking pests are becoming more serious inviting indiscriminate use of pesticides. Hence, the present study was undertaken to assess the "Incidence of sucking pests and natural enemies in cotton under high density planting system (HDPS).” 


\section{Materials and Methods}

Two bulk plots were maintained with $500 \mathrm{~m}^{2}$ area each to study the incidence of sucking pests under normal $(105 \times 60 \mathrm{~cm})$ and high density planting system $(75 \times 10 \mathrm{~cm})$ under unprotected conditions throughout the crop growth period.

\section{Data recorded on sucking pests}

Counts of aphids, leafhoppers, thrips and whiteflies per three leaves one each from top, middle and bottom of plant was recorded on 20 plants from each bulk plot at 15 days interval starting from three weeks after sowing by random selection.

Similarly natural enemies population spider and coccinellids data was collected on whole plant basis on 20 randomly selected plants.

\section{Statistical analysis}

The collected data was transformed to square root transformation and subjected to two sample ' $t$ ' test assuming unequal variances.

\section{Results and Discussion}

Incidence of aphids under high density planting system

The aphid incidence was recorded from 45 to 150 days after sowing (DAS) (Table 1 and Fig.1) at 15 days interval. The data revealed that the aphid population ranged from 2.00 to 25.5 aphids per three leaves in normal spacing, whereas in HDPS 3.50 to 40.50 aphids per three leaves during the crop growth period.

At 60, 75 and 90 DAS there is no significant difference between normal and HDPS. During 105,120 and 135 DAS the aphid incidence was at peak level and there is significant difference between both the spacings and higher aphid incidence was recorded in HDPS than normal spacing. Later at fag end of the crop i.e. at 150 DAS there is no significant difference between the spacings.

Though significant differences were observed between the normal and high density planting, aphid population never crossed ETL (30 aphids per three leaves) in normal spacing whereas, in HDPS aphid population started increasing and crossed ETL at 120 DAS.

The present findings of high incidence of aphids in HDPS conform the results of Kalaichelvi (2008) who found that the infestation of aphids was more at closer spacing of $90 \times 45 \mathrm{~cm}$ (5.06 aphids $/ 3$ leaves) than wider spacing of $90 \times 60 \mathrm{~cm}$ (4.30 aphids 13 leaves $)$ and $120 \times 60 \mathrm{~cm}$ (3.84 aphids $/ 3$ leaves) in $\mathrm{RCH}-2 \mathrm{Bt}$ cotton.

\section{Incidence of leafhopper under high density planting system}

The leafhopper population was observed throughout the season and the incidence was moderate to high up to $120 \mathrm{DAS}$, thereafter declined and reached to a minimum number of 0.45 nos $/ 3$ leaves at 135 DAS in normal spacing and 0.6 nos $/ 3$ leaves in HDPS (Table 1 and Fig. 2).

The incidence of leafhopper population ranged from 0.45 to $5.70 / 3$ leaves and never crossed ETL in normal spacing.

In HDPS leafhopper population ranged from 0.6 to 6.25 per three leaves and crossed ETL twice at 45 DAS again at 75 DAS (6.25 and $6.25 / 3$ leaves).

Though the leafhopper incidence was high in HDPS compared to normal spacing there is no significant difference between two spacings. 
Fig.1 Incidence of cotton aphids (A. gossypii)

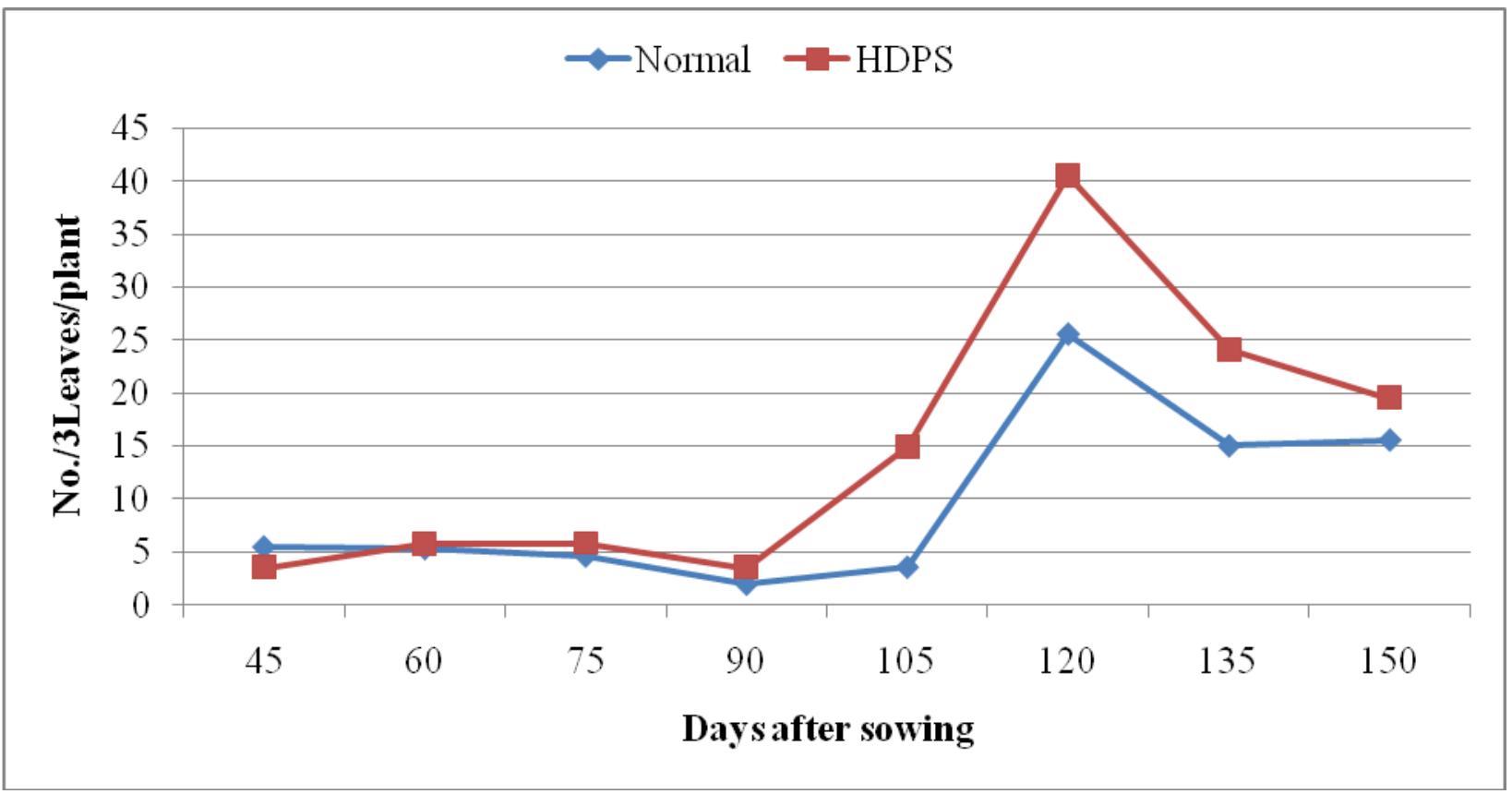

Fig.2 Incidence of cotton leafhopper (A. devastans)

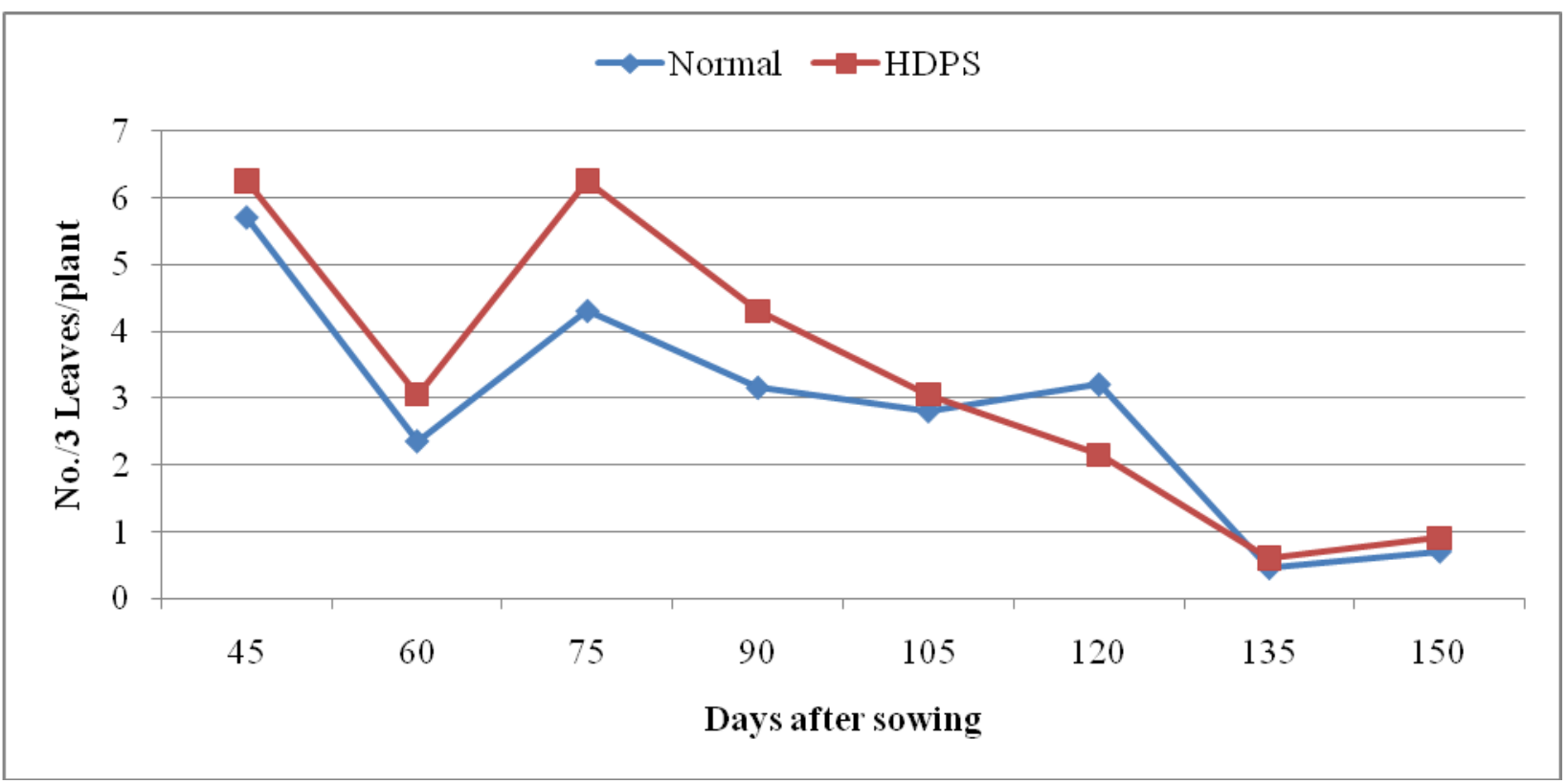


Fig.3 Incidence of cotton thrips (T. tabaci)

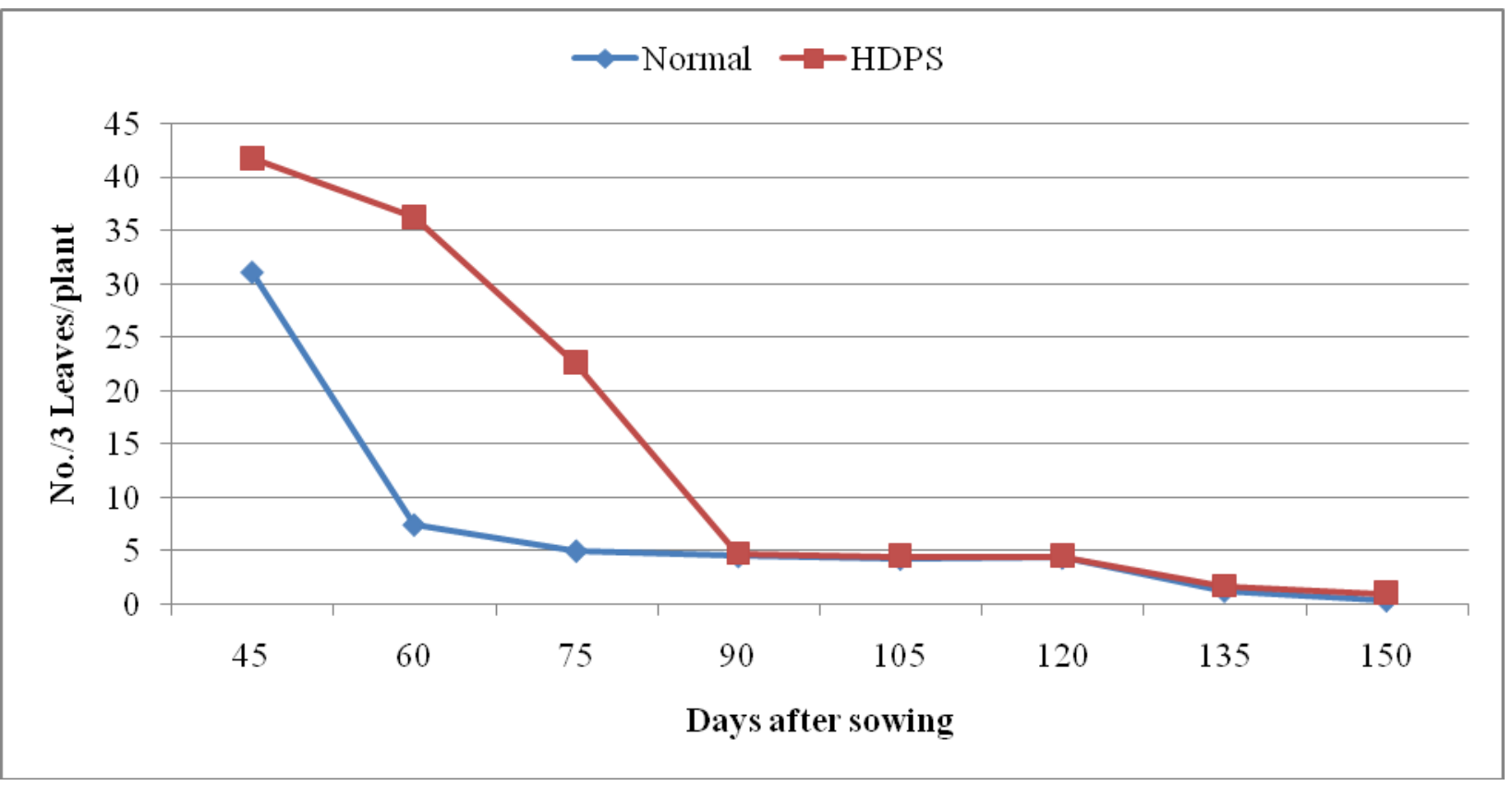

Fig.4 Incidence of cotton whitefly (B. tabaci)

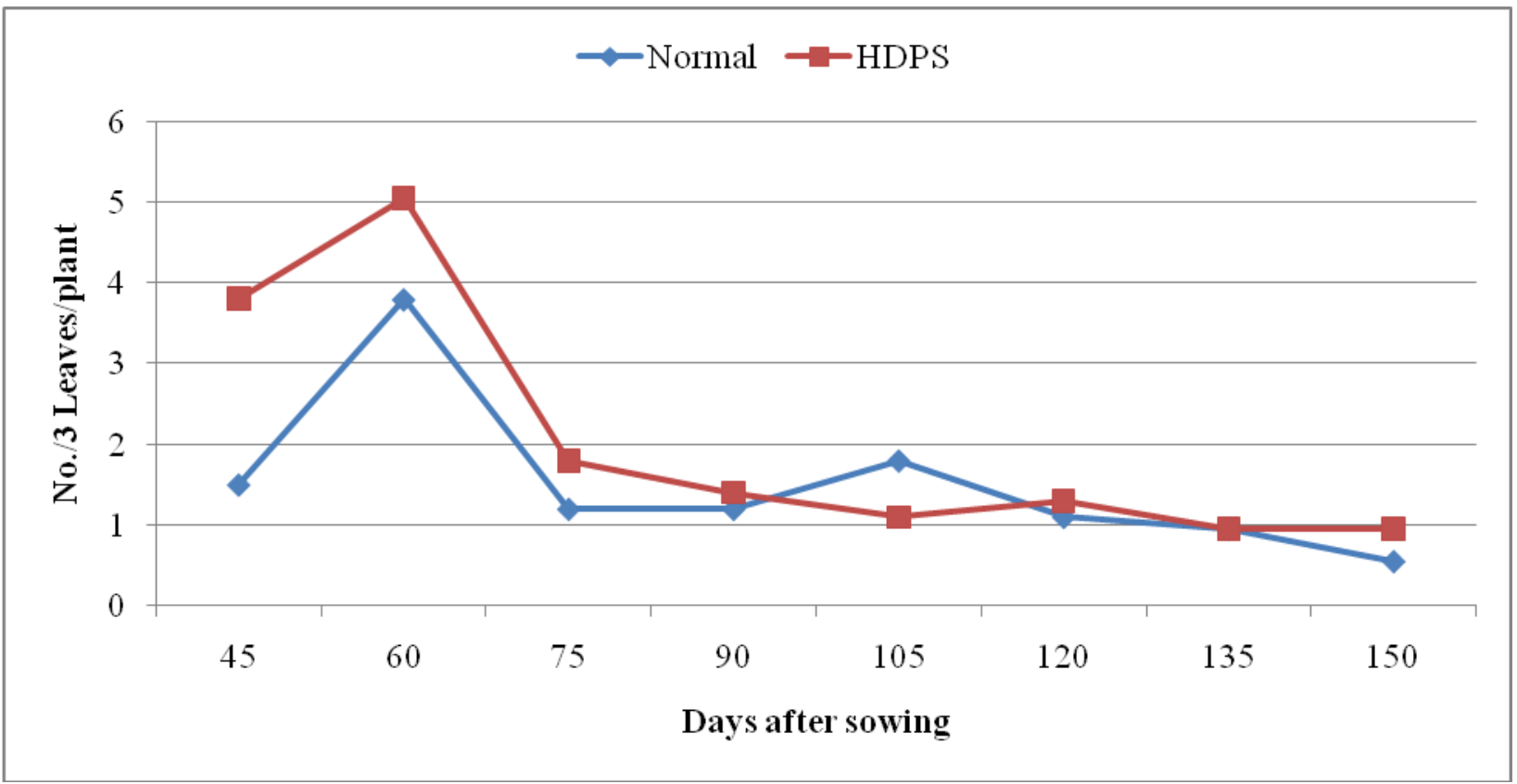


Fig.5 Incidence of spiders

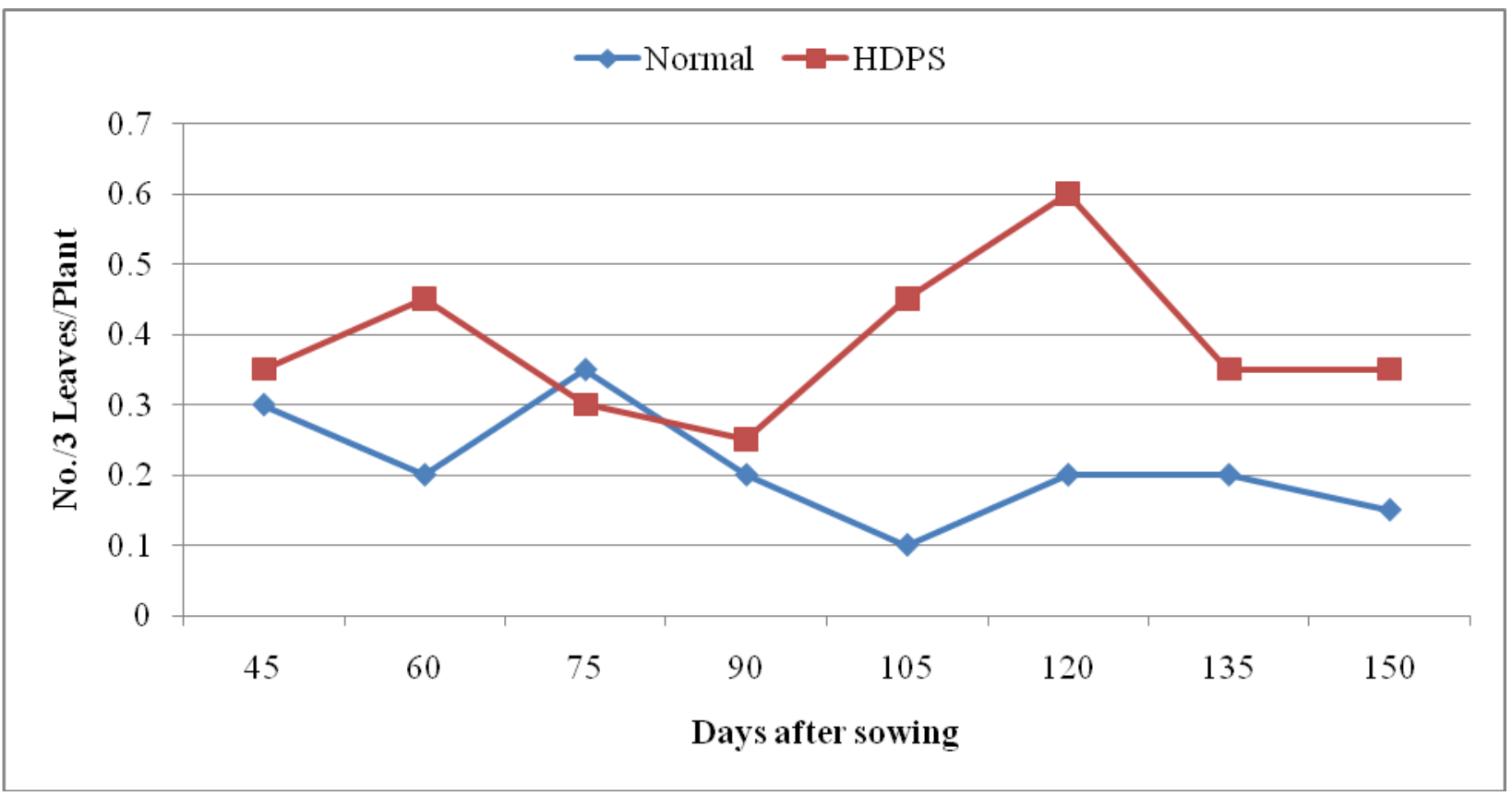

Fig.6 Incidence of coccinellids

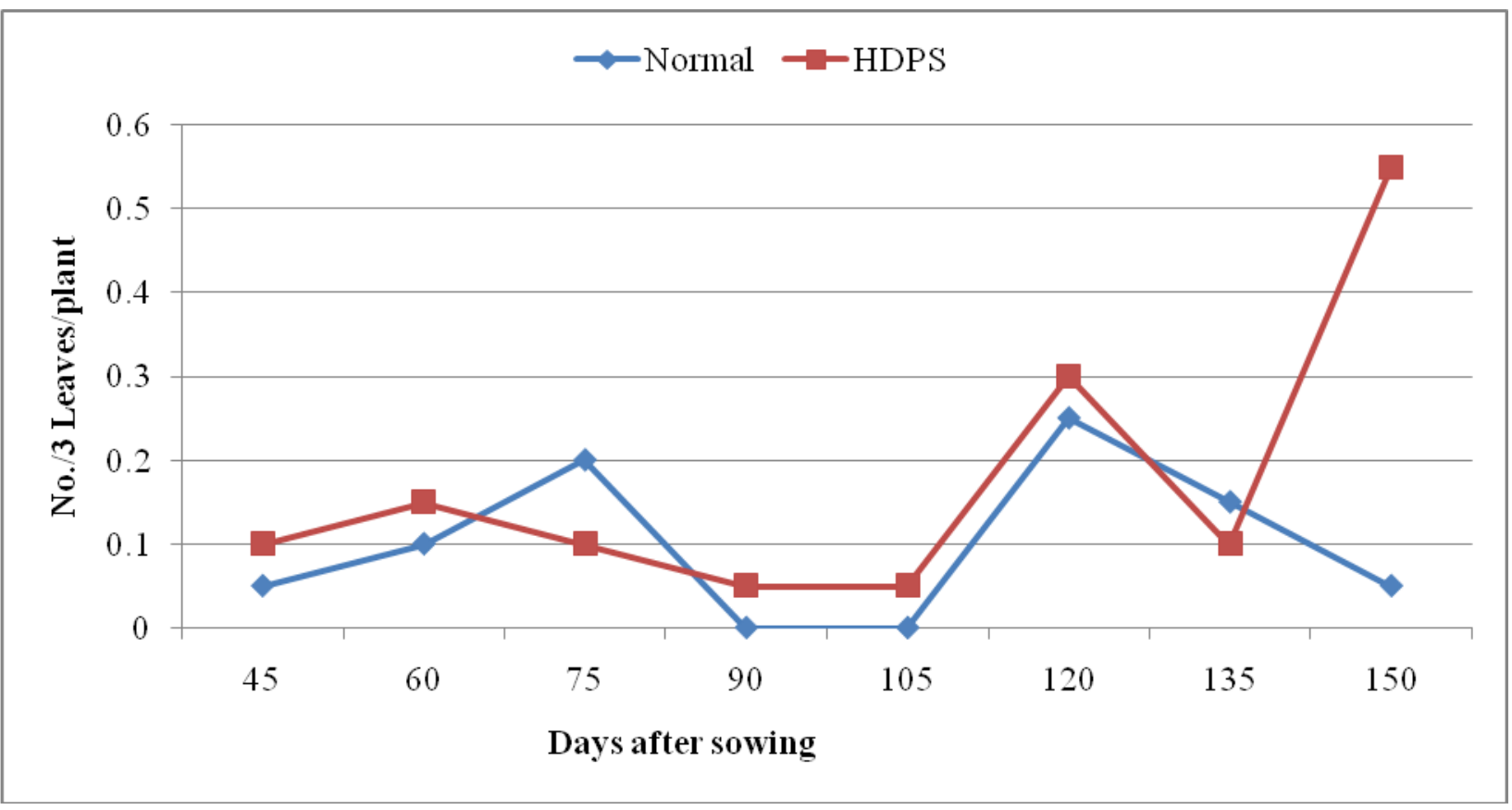


Table.1 Incidence of major sucking pests and natural enemies in cotton under normal and high density planting system in unprotected conditions during Kharif, 2016-17

\begin{tabular}{|c|c|c|c|c|c|c|c|c|c|c|c|c|c|c|c|c|c|c|}
\hline \multirow{3}{*}{ DAS } & \multicolumn{17}{|c|}{ Pest population/3Leaves/Plant } & \multirow[b]{3}{*}{ t-tes } \\
\hline & \multicolumn{2}{|c|}{ Ahids } & \multirow[b]{2}{*}{ t-test } & \multicolumn{2}{|c|}{ Jassid } & \multirow[b]{2}{*}{ t-test } & \multicolumn{2}{|c|}{ Thrips } & \multirow[b]{2}{*}{ t-test } & \multicolumn{2}{|c|}{ Whiteflies } & \multirow[b]{2}{*}{ t-test } & \multicolumn{2}{|c|}{ Spiders } & \multirow[b]{2}{*}{ t-test } & \multicolumn{2}{|c|}{ Coccinellids } & \\
\hline & Normal & HDPS & & Normal & HDPS & & Normal & HDPS & & Normal & HDPS & & Normal & HDPS & & Normal & HDPS & \\
\hline 45 & $\begin{array}{c}5.50 \\
(2.34)\end{array}$ & $\begin{array}{c}3.50 \\
(1.87)\end{array}$ & Sig & $\begin{array}{c}5.70 \\
(2.38)\end{array}$ & $\begin{array}{c}6.25 \\
(2.50)\end{array}$ & NS & $\begin{array}{l}31.05 \\
(5.57)\end{array}$ & $\begin{array}{l}41.75 \\
(6.41)\end{array}$ & Sig & $\begin{array}{c}1.50 \\
(1.22)\end{array}$ & $\begin{array}{c}3.80 \\
(1.94)\end{array}$ & Sig & $\begin{array}{c}0.30 \\
(0.54)\end{array}$ & $\begin{array}{c}0.35 \\
(0.59)\end{array}$ & NS & $\begin{array}{c}0.05 \\
(1.02)\end{array}$ & $\begin{array}{c}0.10 \\
(1.04)\end{array}$ & NS \\
\hline 60 & $\begin{array}{c}5.35 \\
(2.31)\end{array}$ & $\begin{array}{c}5.75 \\
(2.39)\end{array}$ & NS & $\begin{array}{c}2.35 \\
(1.53)\end{array}$ & $\begin{array}{c}3.05 \\
(1.74)\end{array}$ & NS & $\begin{array}{c}7.40 \\
(2.72)\end{array}$ & $\begin{array}{l}36.25 \\
(6.02)\end{array}$ & Sig & $\begin{array}{c}3.80 \\
(1.94)\end{array}$ & $\begin{array}{c}5.05 \\
(2.24)\end{array}$ & NS & $\begin{array}{c}0.20 \\
(0.44)\end{array}$ & $\begin{array}{c}0.45 \\
(0.67)\end{array}$ & Sig & $\begin{array}{c}0.35 \\
(1.16)\end{array}$ & $\begin{array}{c}0.20 \\
(1.07)\end{array}$ & NS \\
\hline 75 & $\begin{array}{c}4.65 \\
(2.15)\end{array}$ & $\begin{array}{c}5.80 \\
(2.40)\end{array}$ & NS & $\begin{array}{c}4.30 \\
(2.07)\end{array}$ & $\begin{array}{c}6.25 \\
(2.50)\end{array}$ & NS & $\begin{array}{c}4.95 \\
(2.22)\end{array}$ & $\begin{array}{l}22.60 \\
(4.75)\end{array}$ & Sig & $\begin{array}{c}1.20 \\
(1.09)\end{array}$ & $\begin{array}{c}1.80 \\
(1.34)\end{array}$ & NS & $\begin{array}{c}0.35 \\
(0.59)\end{array}$ & $\begin{array}{c}0.30 \\
(0.54)\end{array}$ & NS & $\begin{array}{c}0.20 \\
(1.09)\end{array}$ & $\begin{array}{c}0.10 \\
(1.04)\end{array}$ & NS \\
\hline 90 & $\begin{array}{c}2.00 \\
(1.41)\end{array}$ & $\begin{array}{c}3.50 \\
(1.87)\end{array}$ & NS & $\begin{array}{c}3.15 \\
(1.77)\end{array}$ & $\begin{array}{c}4.30 \\
(2.07)\end{array}$ & NS & $\begin{array}{c}4.45 \\
(2.10)\end{array}$ & $\begin{array}{c}4.75 \\
(2.17)\end{array}$ & Sig & $\begin{array}{c}1.20 \\
(1.09)\end{array}$ & $\begin{array}{c}1.40 \\
(1.18)\end{array}$ & NS & $\begin{array}{c}0.20 \\
(0.44)\end{array}$ & $\begin{array}{c}0.25 \\
(0.50)\end{array}$ & NS & $\begin{array}{c}0.00 \\
(1.00)\end{array}$ & $\begin{array}{c}0.10 \\
(1.04)\end{array}$ & Sig \\
\hline 105 & $\begin{array}{c}3.60 \\
(1.89)\end{array}$ & $\begin{array}{r}14.90 \\
(3.96)\end{array}$ & Sig & $\begin{array}{c}2.80 \\
(1.67)\end{array}$ & $\begin{array}{c}3.05 \\
(1.74)\end{array}$ & NS & $\begin{array}{c}4.20 \\
(2.04)\end{array}$ & $\begin{array}{c}4.50 \\
(2.12)\end{array}$ & NS & $\begin{array}{c}1.80 \\
(1.34)\end{array}$ & $\begin{array}{c}1.10 \\
(1.04)\end{array}$ & NS & $\begin{array}{c}0.10 \\
(0.31)\end{array}$ & $\begin{array}{c}0.45 \\
(0.67)\end{array}$ & NS & $\begin{array}{c}0.00 \\
(1.00)\end{array}$ & $\begin{array}{c}0.10 \\
(1.04)\end{array}$ & NS \\
\hline 120 & $\begin{array}{l}25.50 \\
(5.04)\end{array}$ & $\begin{array}{l}40.50 \\
(6.36)\end{array}$ & Sig & $\begin{array}{c}3.20 \\
(1.78)\end{array}$ & $\begin{array}{c}2.15 \\
(1.46)\end{array}$ & Sig & $\begin{array}{c}4.30 \\
(2.07)\end{array}$ & $\begin{array}{c}4.50 \\
(2.12)\end{array}$ & NS & $\begin{array}{c}1.10 \\
(1.04)\end{array}$ & $\begin{array}{c}1.30 \\
(1.14)\end{array}$ & NS & $\begin{array}{c}0.20 \\
(0.44)\end{array}$ & $\begin{array}{c}0.60 \\
(0.77)\end{array}$ & Sig & $\begin{array}{c}0.25 \\
(1.11)\end{array}$ & $\begin{array}{c}0.30 \\
(1.14)\end{array}$ & NS \\
\hline 135 & $\begin{array}{l}15.00 \\
(3.84)\end{array}$ & $\begin{array}{l}24.05 \\
(4.90)\end{array}$ & Sig & $\begin{array}{c}0.45 \\
(0.67)\end{array}$ & $\begin{array}{c}0.60 \\
(0.77)\end{array}$ & NS & $\begin{array}{c}1.20 \\
(1.09)\end{array}$ & $\begin{array}{c}1.70 \\
(1.30)\end{array}$ & NS & $\begin{array}{c}0.95 \\
(0.97)\end{array}$ & $\begin{array}{c}0.95 \\
(0.97)\end{array}$ & NS & $\begin{array}{c}0.20 \\
(0.44)\end{array}$ & $\begin{array}{c}0.35 \\
(0.59)\end{array}$ & Sig & $\begin{array}{c}0.15 \\
(1.07)\end{array}$ & $\begin{array}{c}0.10 \\
(1.04)\end{array}$ & NS \\
\hline 150 & $\begin{array}{l}15.55 \\
(3.94)\end{array}$ & $\begin{array}{l}19.50 \\
(4.41)\end{array}$ & NS & $\begin{array}{c}0.70 \\
(0.83)\end{array}$ & $\begin{array}{c}0.90 \\
(0.94)\end{array}$ & NS & $\begin{array}{c}0.30 \\
(0.54)\end{array}$ & $\begin{array}{c}1.00 \\
(1.00)\end{array}$ & Sig & $\begin{array}{c}0.55 \\
(0.74)\end{array}$ & $\begin{array}{c}0.95 \\
(0.97)\end{array}$ & NS & $\begin{array}{c}0.15 \\
(0.38)\end{array}$ & $\begin{array}{c}0.35 \\
(0.59)\end{array}$ & Sig & $\begin{array}{c}0.05 \\
(1.02)\end{array}$ & $\begin{array}{c}0.60 \\
(1.24)\end{array}$ & Sig \\
\hline Mean \pm SE & $\begin{array}{c}9.64 \\
\pm \\
2.89\end{array}$ & $\begin{array}{c}14.65 \\
\pm \\
4.61\end{array}$ & & $\begin{array}{c}2.83 \\
\pm \\
0.61\end{array}$ & $\begin{array}{c}3.31 \\
\pm \\
0.76\end{array}$ & & $\begin{array}{c}7.23 \\
\pm \\
3.49\end{array}$ & $\begin{array}{c}14.63 \\
\pm \\
5.85\end{array}$ & & $\begin{array}{c}1.51 \\
\pm \\
0.35\end{array}$ & $\begin{array}{c}2.04 \\
\pm \\
0.54\end{array}$ & & $\begin{array}{c}0.21 \\
\pm \\
0.027\end{array}$ & $\begin{array}{c}0.38 \\
\pm \\
0.03\end{array}$ & & $\begin{array}{c}0.10 \\
\pm \\
0.032\end{array}$ & $\begin{array}{c}0.20 \\
\pm \\
0.062\end{array}$ & \\
\hline d.f. & \multicolumn{2}{|c|}{38} & & \multicolumn{2}{|c|}{38} & & \multicolumn{2}{|c|}{38} & & \multicolumn{2}{|c|}{38} & & \multicolumn{2}{|c|}{38} & & \multicolumn{2}{|c|}{38} & \\
\hline t- cal. value & \multicolumn{2}{|c|}{-0.927} & & \multicolumn{2}{|c|}{-0.49} & & \multicolumn{2}{|c|}{-1.085} & & \multicolumn{2}{|c|}{-0.822} & & \multicolumn{2}{|c|}{-3.66} & & \multicolumn{2}{|c|}{-1.41} & \\
\hline
\end{tabular}

Sig: Significant

NS: Non-significant 
The present findings indicate that plant spacing did not show much difference in leafhopper population between normal and HDPS.

Which is in agreement with Arif et al., (2006) who reported that the population of leafhopper did not show significant difference when plant spacing was maintained at $18.5,23.5,30 \mathrm{~cm}$ with the row to row distance of $75 \mathrm{~cm}$ and the population of leafhopper was 1.39, 1.50 and $1.39 / 3$ leaves respectively.

\section{Incidence of thrips under high density planting system}

Thrips population ranged from 0.3 to 31.05 thrips/3 leaves during the crop growth period in normal spacing, whereas in HDPS 1.00 to 41.75/3 leaves (Table 1 and Fig. 3).

Thrips population in HDPS significantly differs with the normal spacing during initial stage of crop growth i.e. at 45, 60, 75 and 90 DAS. Whereas during 105, 120 and 135 DAS there is no significant difference between both the spacings.

Thrips population was observed to be peak and crossed the ETL at 45 and 60 DAS (41.75 and $36.25 / 3$ leaves) in HDPS. In case of normal spacing thrips population crossed ETL only at 45 DAS i.e. 31.05 thrips /3 leaves.

Plant spacing effect on thrips population revealed that less spacing of plant showed significantly higher population of thrips. The present findings are in conformity with the findings of Patel et al., (2015) who reported that the lowest spacing $(120 \times 45 \mathrm{~cm})$ of plants showed significantly highest $(2.84 /$ leaf $)$ thrips population. The lowest $(0.88 /$ leaf $)$ thrips population was recorded in Bt cotton raised at a wider plant spacing $(150 \times 45 \mathrm{~cm})$.

\section{Incidence of whitefly under high density planting system}

The incidence of whitefly population ranged from 0.55 to 3.80 whiteflies per three leaves
(Plate 2d) in normal spacing (Table 1 and Fig 4) and 0.95 to 3.80 in HDPS during crop growth period. The whitefly population in HDPS showed significant difference from normal spacing only at 45 DAS. Thereafter there is no significant difference was found in both the spacings throughout the cropping period (60, $75,90,105,120,135$ and 150 DAS).

Throughout the crop growth period whitefly population did not cross the ETL (30 whitefly's per three leaves) in normal as well as HDPS, it is may be due to the domination of other sucking pests such as jassids, thrips and aphids.

Present findings are not in agreement with the findings of Patel et al., (2015) who found that maximum population of whitefly was recorded (3.97/leaf) from those $B t$ cotton plots raised at plant spacing of $120 \times 45 \mathrm{~cm}$, narrow spacing. The whitefly population decreased significantly i.e. $1.16 /$ leaf with $150 \times 60 \mathrm{~cm}$, wider plant spacing.

\section{Incidence of spiders under high density planting system}

The spider population ranged from 0.10 to 0.35 (105 and 75 DAS) per plant in normal spacing, whereas in HDPS ranged from 0.25 to 0.60 (90 and 120 DAS) per plant during the crop growth period (Table 1 and Fig. 5).

The data indicated that there was significant difference in two spacings on spiders' population during all periods of observation except at 45, 75 and 90 DAS. The peak spider population was observed at 120 DAS $(0.60 / 3$ leaves) in HDPS, at this date of observation the normal spacing recorded 0.20 spiders per plant. The spider population coincide with the of aphid population.

This was in agreement with findings of Patel (2014) who reported that there was significant difference in spiders population at different spacings, being significantly highest in closer spacing of $45 \times 15 \mathrm{~cm}$ than spacing of $60 \times 15 \mathrm{~cm}$ and recommended spacing of $120 \times 45 \mathrm{~cm}$ and 
both later treatments were comparable to each other similar findings of Kalaichelvi (2008) also derive support to the present results, who observed that closer spacing of $90 \times 30 \mathrm{~cm}$ recorded more number of spiders ( 3 spiders per 50 plants) and wider spacing of $120 \times 60 \mathrm{~cm}$ recorded less number of spiders ( 1 spider per 50 plants).

\section{Incidence of coccinellids under high density planting system}

The influence of plant density on coccinellid beetles incidence is presented in table 1 and the population ranged from 0.00 to 0.35 per plant in normal spacing and 0.10 to 0.60 in HDPS during the crop growth period. Coccinellid population in HDPS showed significant difference from normal spacing only at 90 and 150 DAS, remaining days of observations did not show any significant difference between normal and HDPS (Table 1 and Fig. 6).

This was in agreement with the findings of Kalaichelvi (2008) who observed that closer spacing of $90 \times 30 \mathrm{~cm}$ recorded more number of coccinellid beetles ( 4 beetles per 50 plants) and wider spacing of $120 \times 60 \mathrm{~cm}$ recorded less number of coccinellid beetles ( 2 beetles per 50 plants).

\section{References}

Arif, M. J, Gogi, M. D, Mirza M, Zia K and Hafeez, F. 2006. Impact of plant spacing and abiotic factors on population dynamics of sucking insect insect pests of cotton. Pakistan journal biological sciences. 9(7). p. 1364-1396.
Hofs, J.L., Schoeman, A and Vaissayre, M. 2004, Effect of Bt cotton on arthropod biodiversity in South African cotton fields. Communications in Agricultural and Applied Biological Sciences., 69: 191-194.

Kalaichelvi, K. 2008. Effect of plant spacing and fertilizer levels on insect pests in $B t$ cotton hybrids. Indian Journal of Entomology. 70(4): 356-359.

Kranthi, K.R and Kranthi, N. R. 2004, Modelling adaptability of the cotton bollworm, Helicoverpa armigera (Hubner) to Bt cotton in India. Current Sciences., 87: 1096-1107.

Men, X., Ge, F., Edwards, C.A and Yardim, E.N., 2005, The influence of pesticide applications on Helicoverpa armigera and sucking pests in transgenic Bt cotton and non transgenic cotton in China. Crop Protection, 24: 319-324.

Patel, C.K., Bharpoda, T.M., Zala, M.B and Shah, K.D. 2015. Impact of plant spacing and nitrogenous fertilizer on incidence of sucking pests in $B t$ cotton. International journal of plant protection, volume 8 (1): $34-40$

Patel, M.N. 2014. Impact of agronomic practices on incidence of different insect pests and their management in high density planting of cotton. M. Sc Thesis. Navsari agricultural university navsari.

Sharma, H. C. and Pampapathy, G., 2006, Influence of transgenic cotton on the relative abundance and damage by target and non-target insect pests under different protection regimes in India. Crop Protection. 25: 800-813.

\section{How to cite this article:}

Rajasekhar, N. and Durga Prasad, N.V.V.S. 2018. Incidence of Sucking Pests and Natural Enemies in Cotton under High Density Planting System (HDPS). Int.J.Curr.Microbiol.App.Sci. 7(05): 28572864. doi: https://doi.org/10.20546/ijcmas.2018.705.332 